\title{
The Application of Jinping Xi's Excellent Traditional Culture Thought in The Governance of China
}

\author{
Yuanqiao Wang, Ziqing Wei \\ School of Jilin Agricultural University, Changchun 13000, China;
}

Key words: excellent traditional culture, the governance of China

\begin{abstract}
Jinping Xi has always attached great importance to the use of Chinese excellent traditional culture, which is an important source of the idea of the governance of China. Facing the influence and role of excellent traditional culture, which can helps us to understand better of the connotation of traditional culture and can better absorb the wisdom of the history of crystallization, in order to improve the role of excellent traditional culture. Combining traditional culture with China's realities can better build the ideology of the governance of China, which can carry forward the traditional culture and show China's unique charm, so that can make China to develop better.
\end{abstract}

\section{Introduction}

Since the Eighteenth Congress of the Party, Jinping Xi upholds the mind of accelerating the development of Chinese characteristics socialist system and creating a new historical situation with Chinese characteristics, in order to realize the great rejuvenation of the Chinese nation. And through the absorption of China's outstanding traditional culture of historical experience, which formed a series of new ideas of the governance of China.

\section{Pay attention to the influence and function of excellent traditional culture}

The traditional culture of China, which has been baptized and precipitated by 5,000 years, is a good traditional culture that can withstand the scrutiny and speculation. China's outstanding traditional culture has the distinctive characteristics of the Chinese nation, and has accumulated the most profound ideals of the Chinese nation. Earnestly study and understand the excellent traditional culture and inherit the excellent traditional culture, which is an indispensable step for national progress and development. Jinping Xi attaches great importance to the excellent traditional culture; he focuses on and good at learning from the advantages of excellent culture. Jinping Xi stressed at the thirteenth collective study of the Central Political Bureau, Chinese culture has a long history, and it accumulates the deepest pursuit of the Chinese nation and represents the unique spiritual identity of the Chinese nation, which existence for the Chinese nation's endless and development and growth to provide rich nourishment. This show, excellent traditional culture cannot be abandoned the fundamental, is the development of our country must learn from the spirit of food. Jinping Xi stressed at the Confucius Institute in Shandong, a country, a nation of strong, always supported by cultural prosperity, the great rejuvenation of the Chinese nation needs to develop the prosperity of Chinese culture as a condition. A country's governance system is determined by the state's cultural traditions, historical experience and economic development, which is the result of gradual improvement, long-term development and endogenous evolution. Jinping $\mathrm{Xi}$ referred to the fine traditional culture in many speeches and occasions for many times, he has been made the fine traditional culture to develop nutrients into his own distinctive style, and he attaches great importance to the excellent traditional Chinese culture in the development of the important position and role of governing the country. In today's world development situation, we only adhere to the Chinese national character, and heritage of fine traditions, so as to be in the development trend of the world in an invincible position. 


\section{The thought of the governance of China is rooted in the excellent traditional culture of China}

\subsection{Chinese's excellent traditional culture and the rule of law.}

After the Eighteenth Congress of the Party, the Central Leading Group, which represented by Jinping Xi, regarded the rule of law as one of the important principles of the governance of China, and through the expression reflects the degree of emphasis on the rule of law, And then to the rule of law as the core, in the four plenary session of the four sessions of a study and discussion, so that the rule of law as the whole party and the whole society of common concern. The rule of law is the basic strategy of the party leading the people to the governance of China, and the rule of law is the basic way of the governance of China. China's rule of law has been passed for thousands of years, the content is very rich, and the rule of law in China has played a very large role in guiding. For example, everyone is equal before the law and the emperor committed the crime with the common people in Chinese's excellent traditional culture are very similar. Implement the rule of law in accordance can better play the role of rule of law in state governance and social management and laws and regulations govern the state, and laws and regulations are in disarray are also have similarities. Adhere to the rule of law and the rule of virtue and Wang Chong's thinking of moral and law are also very similar. Those who serve the law are strong and strong, and those who serve the law are weak, which is not only expressed the general secretary of Jinping $\mathrm{Xi}$ adhere to the concept of the governance of China, but also reflects the general secretary of Jinping Xi the rule of law and excellent traditional culture in the same vein and consistent with the content.

\subsection{Chinese's excellent traditional culture and the cultivation of clean government.}

Since the founding of the Communist Party of China, it has paid great attention to the building of the Party's clean government and always grasped the party's style. Jinping Xi has always insisted on strengthening anti-corruption, emphasizing the building of party members and cadres of clean government. We must unswervingly push forward our party's anti-corruption construction and sum up and accumulate the successful experience of combating corruption and corruption in a long practice. But also need to refer to the history of anti-corruption and good traditional culture, and the use of the wisdom of the ancients and increase efforts to promote the construction of anti-corruption, we should take the lessons of history as a warning. The construction of clean government is the hub of the party building; we must always remember the meaning of wormwood fold, the gap wall is broken, and to punish corruption. We will adhere to fight the tigers and flies, effectively protect the legitimate rights and interests of the people, and strive to achieve the integrity of the cadres and the government. In addition, we must also strengthen the history of China's anti-corruption efforts to sum up, carry forward the good ideas of honest officials, to abandon corrupt officials of the negative corruption.

\subsection{Chinese's excellent traditional culture and the foreign policy of peace.}

In diplomacy, Jinping Xi constantly learns from ancient times to the best ideas, and integration in the peaceful foreign policy, and then formed a unique informal diplomacy. Jinping Xi upholds the "good" traditional thinking; continue to lead the Chinese people to take the road of peaceful development. Jinping Xi once mentioned: Although China is the history of the world's most powerful country, but there is no aggression and colonization of other countries, which indicate that the Chinese nation has always loved peace. In recent years, China has paid more attention to the surrounding diplomatic work. On the basis of the concept of amity, sincerity, mutual benefit and inclusiveness, we have built the Silk Road Economic Zone and Maritime Silk Road. On the basis of win-win cooperation, we will learn from each other, learn from each other and promote each other. Conform to the trend of the times, build a new type of big power relations, and promote the BRICS strategic cooperation, pay attention to the development of relations with the United States. We must strengthen cooperation with developing countries, promote new development of Sino-Latin American relations, deepen Sino-Arab cooperation, and always make reliable friends and sincere partners with developing countries. Since ancient times, the Chinese nation advocated Concorde, and this idea is also deeply into the blood of the Chinese people, embodies the Chinese people has always been a good wish, but also our country to deal with the basic concept of relations with other countries. 


\section{References}

[1]. Jinping Xi. Conscientiously implement the spirit of the Third Plenary Session of the Eighteenth Central Committee of the Communist Party of China and bring together the powerful positive energy [N].People's Daily. 2013-11-29, (01).

[2]. Jinping Xi. Xi Jingping: The Governance of China[M]. Foreign Languages Press. 2014, p.138.

[3]. People's Daily commentary Department. Xi Jinping Code[M]. People's Daily Press. 2015, p.221.

[4]. Jinping Xi. Speech at the German Colbert Foundation [N]. People's Daily. 2014-3-30(02).

[5]. Information on: http://www.gov.cn/ldhd/2014-02/25/content_2621669.htm. 